\title{
Dry matter accumulation and seed yield in faba bean (Vicia faba L) genotypes
}

\author{
N Nachi ${ }^{*}, J$ Le Guen \\ Station d'amélioration des plantes, domaine de la Motte, Inra, BP 29, F-35650 Le Rheu, France
}

(Received 21 July 1995; accepted 24 November 1995)

\begin{abstract}
Summary - Fifteen genotypes of spring faba bean, differing in flowering earliness, in growth habit (one determinate genotype and 14 indeterminate genotypes) and in mean seed weight, have been analysed for dry matter accumulation and for seed yield elaboration during the two years 1992 and 1993. For all the characters analysed, significant effects of genotypes and year were observed. The hybrid AEC presented a large accumulation of dry matter and a high yield. In comparison to other genotypes, its hybrid vigour seemed to let it transfer more of the dry matter accumulated early by its tillers, to the elaboration of its seed yield. With the exception of tillering, no difference has been established between the determinate genotype B1064 and the indeterminate ones. The size of the seeds sown and the date of flowering appeared closely correlated to dry matter accumulated at vegetative and beginning of flowering stages respectively and seemed to be good indicators of genotype vigour. The amount of dry matter accumulated at date 3 (beginning of young pod stage) in the main stem appeared to be a good early indicator of the number of seeds per $\mathrm{m}^{2}$ and of the mean seed weight. The dry weight of plant at date 4 (pod at stage II) was positively and significantly correlated to seed yield. Seed yield was mainly correlated to the number of produced seeds per $\mathrm{m}^{2}$.
\end{abstract}

Vicia faba L = faba bean / genetic variability / dry matter accumulation / yield / yield components / early indicator

Résumé - Accumulation de matière sèche et rendement chez les génotypes de féverole (Vicia faba $L$ ). Quinze génotypes de féverole de printemps, différant par leur précocité de floraison, leur croissance déterminée (un génotype) ou indéterminée (14 génotypes) et le poids moyen d'une graine ont été analysés pour leur accumulation de matière sèche et leur élaboration du rendement, durant les deux années 1992 et 1993. Pour l'ensemble des caractères analysés, des différences significatives ont été observées entre les génotypes et entre les années. L'hybride AEC a présenté une forte accumulation de matière sèche et un rendement en graines élevé. Par rapport aux autres génotypes, sa vigueur hybride semble lui permettre une meilleure utilisation de la matière sèche accumulée précocement par ses talles dans l'élaboration de son rendement. Pour la plupart des caractères analysés, aucune différence n'a été établie entre le génotype déterminé B1064 et les génotypes indéterminés. La taille des semences et la date de floraison, fortement corrélées à la matière sèche accumulée au stade végétatif et au stade début floraison, semblent être de bons indicateurs de la vigueur végétative des génotypes. La quantité de matière sèche accumulée à la date 3 (début stade jeunes gousses) par la tige principale apparaît comme un indicateur semi-précoce du nombre de graines et du poids moyen d'une graine. Le poids sec de la plante à la date 4 (stade gousses II) est corrélé positivement et significativement au rendement grainier. Le rendement grainier est principalement corrélé au nombre de graines par $m^{2}$.

Vicia faba $L$ = féverole / variabilité génétique / accumulation de matière sèche / rendement / composantes du rendement / indicateurs précoces

\footnotetext{
* Correspondence and reprints.

Abbreviations: 1Flo: date of flowering; NP/m2: number of pods per $\mathrm{m}^{2} ; \mathrm{NS} / \mathrm{m}^{2}$ : number of seeds per $\mathrm{m}^{2} ; \mathrm{MSW}$ : mean seed weight; SY: seed yield; DM: dry matter or biomass; DM rep: reproductive dry matter; ${ }^{\circ} \mathrm{C} . \mathrm{D}$ : degree-day; SWC: soil water capacity; $r$. correlation coefficient; $r^{2}$ : determination coefficient; $d f$ degree of freedom; $P$ : probability level; $m^{2}$ : square meter.
} 


\section{INTRODUCTION}

Faba bean (Vicia faba $L$ ) seeds represent a valuable source of protein, especially for animal feeding as their protein content ranges from 25 to $35 \%$ of dry matter. However, the seed yield of the presently available faba bean cultivars is unreliable. One of the main expressions of yield instability is excessive flower and pod abortion, which can reach up to $87 \%$ of the number of flowers (Kambal, 1969; Gates et al, 1983).

One factor responsible for the high frequency of abortions is the competition for assimilates between vegetative and reproductive compartments. This competition is the result of an excessive vegetative development and the overlapping of the vegetative and reproductive phases, which is long in the indeterminate cultivars of faba bean (Jaquiéry and Keller, 1978; Chapman et al, 1979; Bond, 1986). In order to reduce the competition between vegetative and reproductive growth during pod filling, recent approaches have included the development of alternative types of plant with a strong emphasis on determinate growth habit (Berthelem et al, 1984; Bond, 1986; Stützel and Aufhammer, 1992). A determinate form of faba bean is based on the $t i$ (terminal inflorescence) mutation (Sjödin, 1971). Its terminal inflorescence induces an earlier termination of the elongation of each stem, which may shorten the growth period. In this type of plant, intra-plant competition for assimilates between reproductive and vegetative organs is then dramatically limited in favour of pod setting and seed fitting (Filippetti et al, 1983; Berthelem et al, 1984; Koscielniak et al, 1990; Stützel and Aufhammer, 1992).

Another way to increase seed yield stability would be to select early flowering types. This would let the plants complete the very long reproductive phase before the climatic conditions (high temperatures and hydric stress) become too drastic. The climatic conditions induce excessive abortions of reproductive organs (Poulsen, 1974; Magyarosi and Sjödin, 1976; Le Guen, 1990).

A change in the architecture and in the flowering earliness of faba bean plants may also affect seed yield. However, the determinate genotypes presently available yield less than the indeterminate ones, and early flowering genotypes also produce less than late flowering ones (Saxena et al, 1986; Bond, 1987; Pilbeam et al, 1989a). In several grain legumes, it has also been demonstrated that increased seed yields of improved cultivars may be obtained through an increase in total biomass production or through changes in the partitioning of dry matter between vegetative and reproductive organs (in soybean: Egli et al, 1985; Lejeune-Henaut, 1992; peas: Turc, 1988; Dumoulin, 1994; and lupins: Duthion et al, 1987a; Julier et al, 1993).

The objective of the present study was to determine some early indicators of yield and/or yield components, which could be used in breeding programmes. First, dry matter accumulation in different organs was analysed during the growth period for different spring faba bean genotypes, characterized by indeterminate and determinate growth and by flowering types. Then, seed yield and yield components were investigated. Finally, relationships between total dry matter accumulated during the growing period and seed yield were analysed.

\section{MATERIALS AND METHODS}

Fifteen spring-sown faba bean genotypes ( $V$ faba $L$ ), differing in flowering earliness, growth habit and mean seed weight were used in this study. The main characteristics of these genotypes are summarized in table I.

Field trials were conducted in France at Station d'amélioration des plantes, INRA, Rennes, in a clay silt soil with $\mathrm{pH} \mathrm{6}$, and an available soil water capacity (SWC) of $90 \mathrm{~mm}$ within the rooting zone. From March to August 1992 the total precipitation was $284 \mathrm{~mm}$, and $209.5 \mathrm{~mm}$ from March to August 1993. Rain was regularly distributed through the 1992 growing period with a slight water deficit at the very end of maturation, but during 1993 water deficit occurred earlier and was more severe.

The experimental design was a randomized complete block with three replications. The genotypes were sown in 15-row plots $(3 \mathrm{~m}$ long $\times 0.45 \mathrm{~m}$ between rows), at a plant density of 10 plant $/ \mathrm{m}^{2}$, to avoid strong competition between genotypes. This density was obtained after hand-thinning the plots at the three-leaf stage. Sowing dates were $8 / 3 / 92$ and $9 / 3 / 93$ and emergence dates were $30 / 3 / 92$ and 25/3/93

During both growing seasons, five samplings of five plants per plot were made for each cultivar. The first sampling occurred at the five-leaf stage (date 1) and the second one at the beginning of flowering (date 2). The third sampling (date 3 ) was made when young pods on the first reproductive node on main stem were $2 \mathrm{~cm}$ long (pods at stage I). Then, when the pods reached $5 \mathrm{~cm}$ during the seed-filling phase (pods at stage (I), the fourth sampling was made (date 4). These two stages correspond to the stages described by Poulsen (1977). The final sampling was made at full maturity (date 5). For each sampling plant, main stem and basal branches (tillers) were separated. Then, leaves and reproductive organs of the main stem, including flower buds, flowers and pods at stages I and 
Table I. Characteristics of $V$ faba $L$ genotypes used in this study (GEVES, 1994).

\begin{tabular}{|c|c|c|}
\hline Genotype & Breeder & $\begin{array}{c}\text { Registration } \\
\text { year }\end{array}$ \\
\hline
\end{tabular}

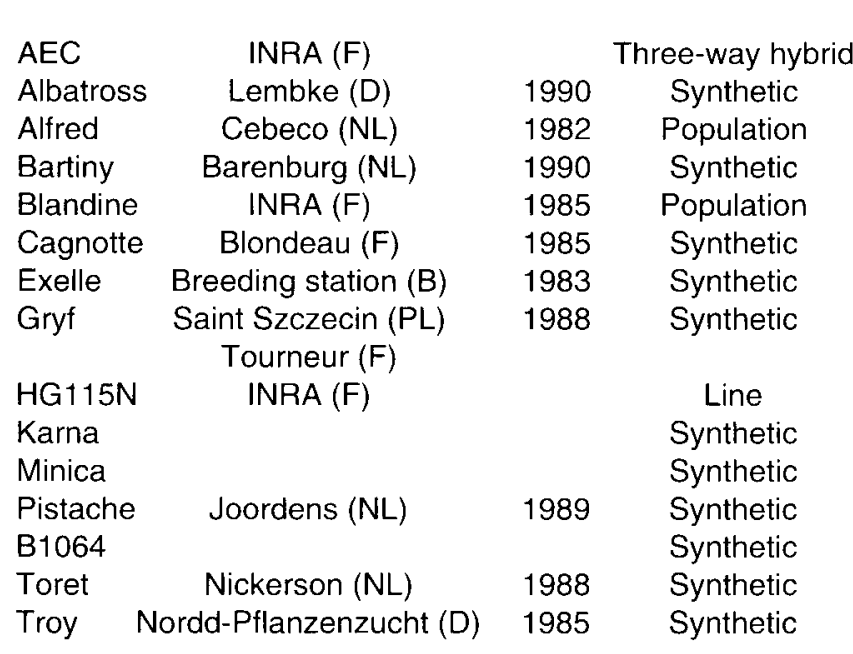

* Lots of seed used for both years of experiment.

II, were also separated. Dry weights were obtained after oven drying at $80 \pm 5^{\circ} \mathrm{C}$ for $48 \mathrm{~h}$.

For both seasons, border rows were discarded and a sub-plot $\left(1 \mathrm{~m}^{2}\right)$ was combined in each plot at maturity. Number of pods per square meter $\left(\mathrm{NP} / \mathrm{m}^{2}\right)$, number of seeds per $\mathrm{m}^{2}\left(\mathrm{NS} / \mathrm{m}^{2}\right)$, mean seed weight (NSW) and seed yield were calculated.

At each sampling date, data related to dry matter, yield and its components were analysed using the mean value of the five plants. Variance analysis of the genotype plot means was conducted for both years pooled. After a significant $F$, this analysis of variance was followed by the Neuman and Keuls (SNK) test at the $5 \%$ level for ranking means of genotypes. When the genotype $x$ year interaction was not significant, only the mean obtained for both years is presented; when the interaction was significant, the ranking of the genotypes is presented for each year.

\section{RESULTS}

\section{Biomass production}

For 1992 and 1993, total dry matter accumulation per unit area increased with time until date 4 and then began to decline. At each sampling date a significant difference was found between the two years for the total amount of biomass accumula-

\section{Physiological and agronomic characteristic}

$\begin{array}{cc}\begin{array}{c}\text { Earliness of } \\ \text { flowering }\end{array} & \begin{array}{c}\text { Plant habit } \\ \text { at } 0 \% \text { moisture* }\end{array}\end{array}$


Table II. Analysis of variance of total dry matter accumulated by square meter $\left(\mathrm{DM} / \mathrm{m}^{2}\right)$ at five sampling dates for 15 genotypes and for two seasons (1992 and 1993).

\begin{tabular}{|c|c|c|c|c|}
\hline Source of variation & $d f$ & Mean square & $\mathrm{F}$ value & $P>F$ \\
\hline \multicolumn{5}{|l|}{ Date 1} \\
\hline Genotype & 14 & 41.46 & 3.69 & 0.0001 \\
\hline Year & 1 & 176.40 & 15.70 & 0.0001 \\
\hline Block (year) & 4 & 16.03 & 1.42 & 0.1629 \\
\hline Genotype $x$ year interaction & 14 & 7.78 & 0.68 & 0.6140 \\
\hline Error & 56 & 11.23 & & \\
\hline
\end{tabular}

\section{Date 2}

Genotype
Year
Block (year)
Genotype $x$ year interaction
CV $=26.55 \%$

Date 3

Genotype

Year

Block (year)

Genotype x year interaction

Error

$\mathrm{CV}=25.08 \%$

Date 4

Genotype

Year

Block (year)

Genotype x year interaction

Error

$\mathrm{CV}=17.82 \%$

Date 5

Genotype

Year

Block (year)

Genotype x year intraction

Error

$C V=17.82 \%$

14
1
4
14
56

412.32
21591.51
52.21
179.42
211.03

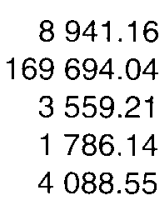

$\begin{array}{rr}14 & 8941.16 \\ 1 & 169694.04 \\ 4 & 3559.21 \\ 14 & 1786.14 \\ 56 & 4088.55\end{array}$

2.19

41.50

0.0045

0.87

0.4747

0.44

0.9757
0.0395

0.0001

0.7817

0.6139

$\begin{array}{rr}14 & 20100.28 \\ 1 & 1390792.71 \\ 4 & 5940.45 \\ 14 & 6431.12 \\ 56 & 6929.80\end{array}$

2.90

0.0024

200.70

0.0001

0.86

0.4754

0.93

0.7504

Table III. Total dry matter accumulated per $\mathrm{m}^{2}\left(\mathrm{~g} / \mathrm{m}^{2}\right)$ at five sampling dates during the 1992 and 1993 seasons.

Date

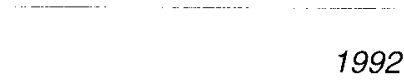

Mean

10.10

95.68

684.46

1093.08

771.02

1992

67111.90
95591.51
2970.22
4387.94
13339.27

5.03

0.0001

14

4

14

56

13339.27
7.17

0.22

0.0021

0.33

0.7859

0.9874
1993
2

4

5

SE: standard error.
$S E$

1.60

10.79

50.65

54.78

59.71
Mean

21.95

117.64

419.46

672.94

487.04
SE

1.01

8.66

25.30

40.50

30.25 
Table IV. Dry matter accumulated per square meter $\left(\mathrm{g} / \mathrm{m}^{2}\right)$ at five sampling dates over two years.

Genotype

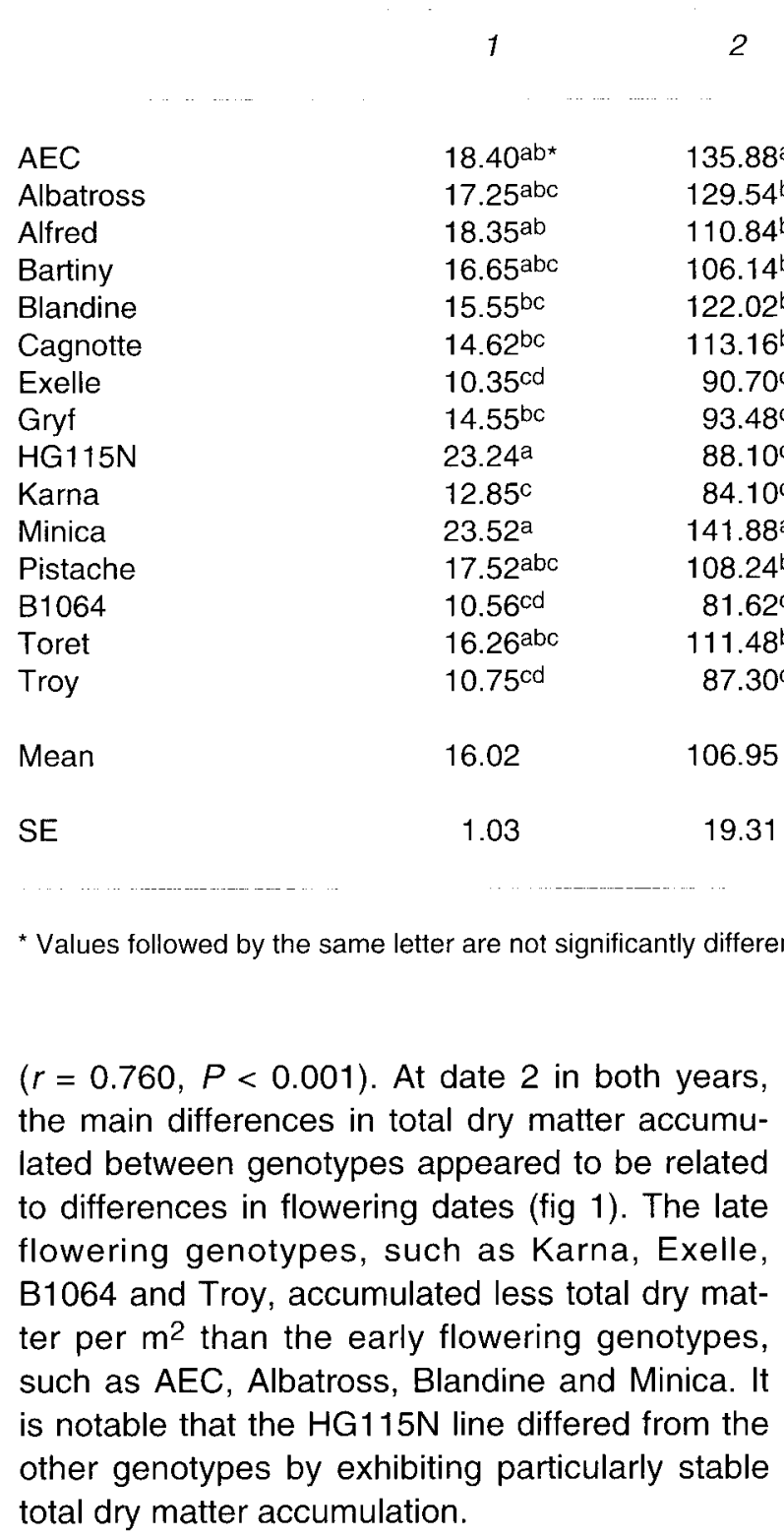

Correlation coefficients of total dry matter of reproductive organs at harvest (date 5) and total dry matter accumulated by the plant and by different parts of the plant during growing phases, for the 15 genotypes and for each year of the experiment, are given in table $\mathrm{V}$. For both years the relationships between the characteristics were similar. No significant correlation was found between the dry matter accumulated by the plant, or by different parts of the plant, at date 1 and the dry matter of the reproductive organs at date 5 . The total dry matter of the reproductive organs at date 5 was positively correlated with the dry matter of the main stem from dates 2 to 5 and with the dry matter accumulated by the plants at dates 4 and 5 . Strong correlations were found between

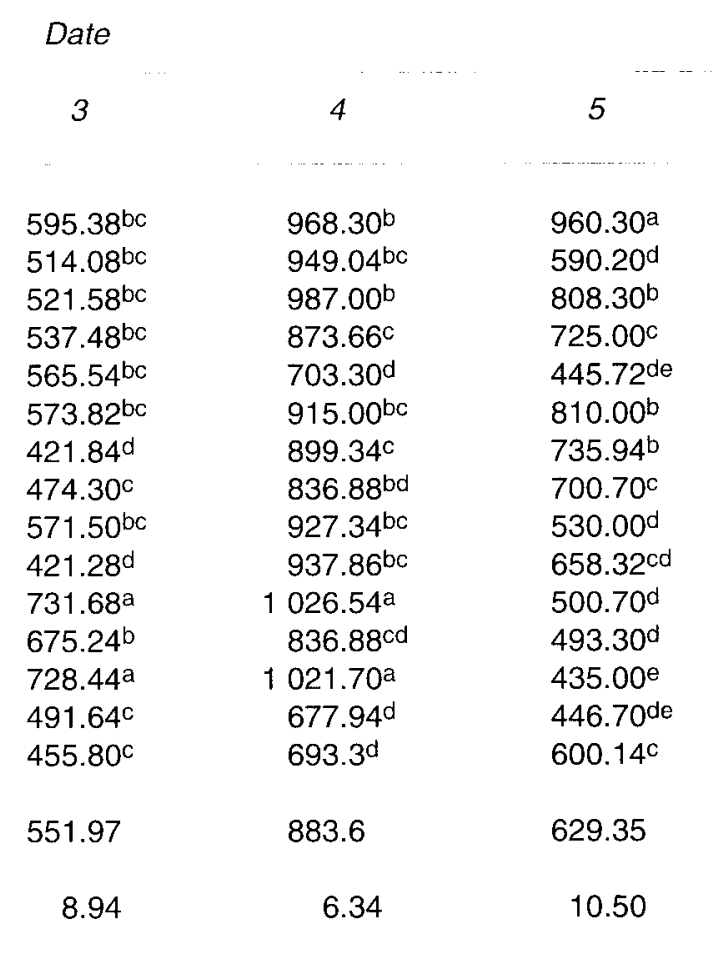

the dry matter of the main stem from dates 2 to 5 and the dry matter of the reproductive organs at date 5. Dry weights of tillers from dates 2 to 3 were negatively correlated with the dry weight of the reproductive organs at date 5 . However, for hybrid AEC, the high accumulation of dry matter in the tillers was not linked to the total dry matter accumulated by its reproductive organs at date 5 (fig 2). A strong relationship was found between the biomass of the reproductive organs at dates 4 and 5 .

\section{Seed yield and components of yield}

The seed yield $\left(\mathrm{tha}^{-1}\right)$ and the numbers of seeds and pods per $\mathrm{m}^{2}$ were significantly different between years (table VI). Significantly higher values, except for mean seed weight, were obtained for seed yields and its components in the first year of experiment than in the second (table VII). The number of pods per $\mathrm{m}^{2}$ were only reduced by $22 \%$. No significant interaction between genotype and year was found for seed yield or its components (table VI).

Seed yield varied among genotypes: the top yielding genotypes, hybrid $A E C$, followed by 
Alfred (3.7 $\left.\mathrm{t} \mathrm{ha}^{-1}\right)$, significantly outyielded Blandine (2.3 tha-1) (table VIII). The determinate genotype B1064 and the indeterminate ones, Exelle, Troy and Toret, had the lowest yields (on average $2.7 \mathrm{tha}^{-1}$ ). The number of seeds per $\mathrm{m}^{2}$ was significantly higher for Karna than for
HG115N. The number of pods 2 was greater for Bartiny and Karna than for Toret and HG115N (table VIII). There was a significant difference among genotypes in mean seed weight (table VI). The HG115N line, followed by the Minica population, had a mean seed weight significantly
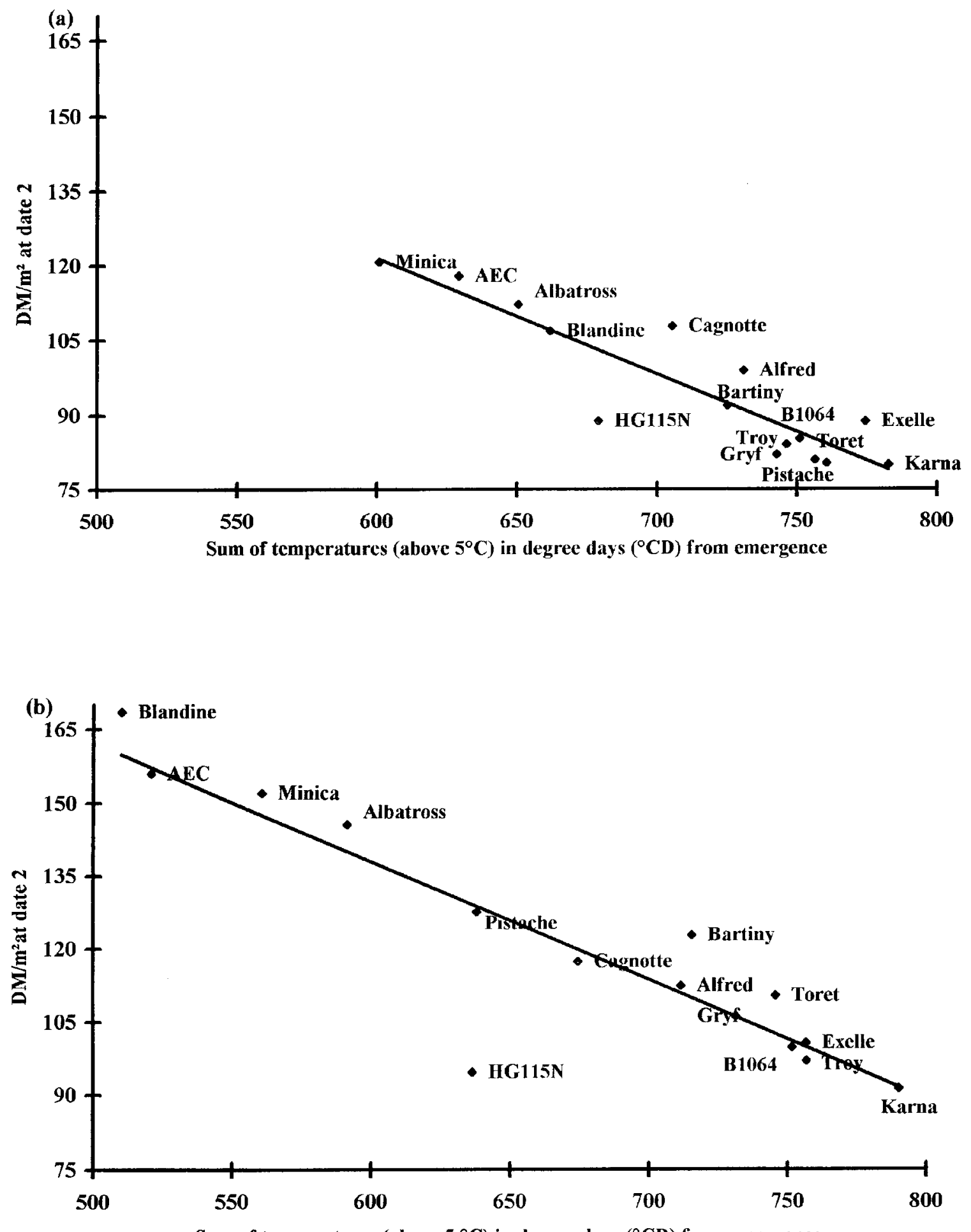

Sum of temperatures (above $5{ }^{\circ} \mathrm{C}$ ) in degree days $\left({ }^{\circ} \mathrm{CD}\right)$ from emergence

Fig 1. Relationship between total dry matter per square meter $\left(\mathrm{DM} / \mathrm{m}^{2}\right)$ at sampling date 2 and date of flowering (1Flo), measured by sum of temperatures (above $5{ }^{\circ} \mathrm{C}$ ) from emergence, for both seasons. (a) Regression equation for 1992 data: DM/ $\mathrm{m}^{2}=261.05$ $( \pm 8.42)-0.239( \pm 0.05)$ 1Flo, $r^{2}=0.87, d f=13$. (b) Regression equation for 1993 data: $\mathrm{DM} / \mathrm{m}^{2}=284.24( \pm 6.60)-0.248( \pm 0.01)$ 1Flo, $r^{2}=0.81, d f=13$ 
Table V. Correlation coefficients between reproductive dry matter accumulated at harvest (date 5) and total dry matter of plant, and of different organs at early sampling dates, for 1992 and 1993

\begin{tabular}{|c|c|c|c|c|c|c|c|c|c|c|}
\hline & & & 1992 & & & & & 1993 & & \\
\hline & Plant & Main stem & Leaves & Tiller & $\begin{array}{l}\text { Reproductive } \\
\text { organs }\end{array}$ & Plant & Main stem & Leaves & Tiller & $\begin{array}{c}\text { Reproductive } \\
\text { organs }\end{array}$ \\
\hline & & & & & & & & & & \\
\hline & - & - & - & - & - & - & - & - & - & - \\
\hline 2 & - & $0.690^{b}$ & $0.445^{a}$ & $-0.453^{a}$ & - & - & $0.677^{b}$ & $0.697^{b}$ & $-0.475^{a}$ & - \\
\hline 3 & - & $0.667^{b}$ & - & $-0.660^{b}$ & - & - & $0.557^{a}$ & - & $-0.759^{b}$ & - \\
\hline 4 & $0.470^{a}$ & $0.454^{a}$ & - & - & $0.765^{b}$ & $0.499^{a}$ & $0.445^{\mathrm{a}}$ & - & - & $0.862^{b}$ \\
\hline 5 & $0.982^{b}$ & $0.554^{a}$ & - & - & 1.000 & $0.987^{b}$ & $0.578^{a}$ & - & - & 1.000 \\
\hline
\end{tabular}

The threshold of significance at $5^{\mathrm{a}}$ and $1 \% \mathrm{~b}$ levels, for $d f=13$; only significant correlation coefficients are given.

greater than other genotypes. The lowest seed weights were recorded for Alfred, Karna, Troy, Gryf and Exelle. B1064 and the other genotypes presented intermediate values (table VIII). On average, the contribution of main stem and tillers

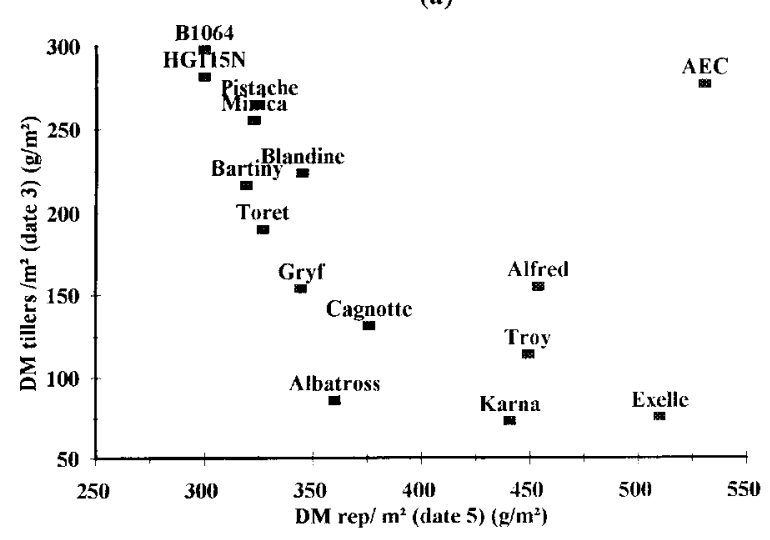

(b)

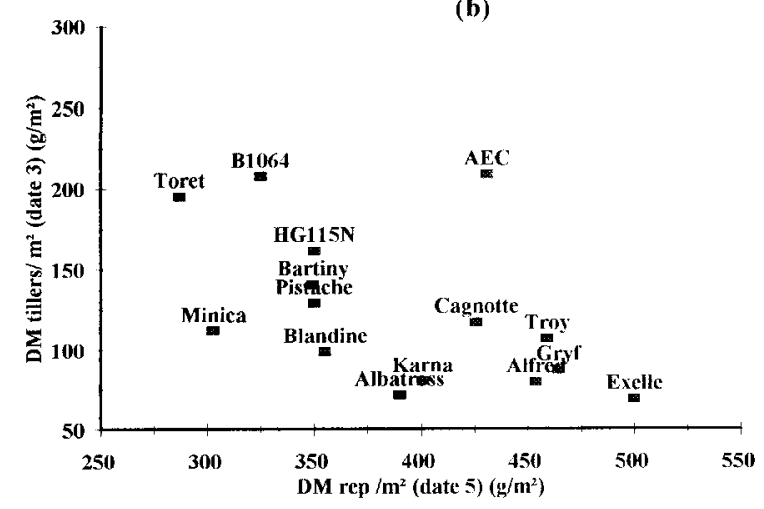

Fig 2. Relationship between reproductive dry matter accumulated per square meter (DM rep/m $/ \mathrm{m}^{2}$ ) at complete maturity (date 5) and dry matter accumulated by tillers at date 3 , for 15 genotypes and for each season, 1992 (a) $(r=-0.682, P<$ $0.01)$ and 1993 (b) $(r=-0.651, P<0.01)$. to the total number of the seeds varied with the genotype (fig 3 ). For both seasons and for most of the faba bean genotypes, the main stem contributed most of the seeds (> 65\%). However, for B1064 and Toret, the main stem and the tillers supplied equal contributions of seeds. These differences in the contribution of main stem and tillers to seed yield did not result from the numbers of tillers formed per plant, since no significant correlation between these components was found.

For both years, correlation coefficients between seed yield and number of seeds, seed yield and mean seed weight were significant (table IX). Seed yield was highly correlated with the number of seeds per $\mathrm{m}^{2}$, while it was weakly correlated with mean seed weight. A high negative correlation between the number of seeds per $\mathrm{m}^{2}$ and mean seed weight was found. The mean seed weight was also negatively correlated to the number of pods per $\mathrm{m}^{2}(r=-0.564$ $-0.618, P<0.05$ ).

\section{Seed yield and total biomass accumulated by the plant and by parts of plant}

For both years significant correlations between the seed yield, its components (number of seeds and mean seed weight) and the total biomass accumulation during the growth period (from dates 2 to 5 ) were established (table IX). Correlation coefficients did not differ significantly $(P=0.05)$ from one year to the other. Seed yield was positively correlated with the dry weight of the reproductive organs at date 5 (harvest) and with the total dry matter accumulated by the plant at date 4. A positive correlation was also noted 
Table VI. Analysis of variance of seed yield and yield components for 15 genotypes and for two seasons (1992 and 1993).

\begin{tabular}{|c|c|c|c|c|}
\hline Source variation & df & Mean square & F value & $P>F$ \\
\hline \multicolumn{5}{|l|}{ Seed yield } \\
\hline Genotype & 14 & 9799.45 & 5.71 & 0.0001 \\
\hline Year & 1 & 36838.42 & 21.45 & 0.0001 \\
\hline Block (year) & 4 & 227.09 & 0.13 & 0.8715 \\
\hline Genotype x year interaction & 14 & 1486.99 & 0.87 & 0.5609 \\
\hline Error & 56 & 1717.16 & & \\
\hline \multicolumn{5}{|l|}{$C V=20.79 \%$} \\
\hline \multicolumn{5}{|l|}{ Number of poids $/ m^{2}$} \\
\hline Genotype & 14 & 25180.40 & 2.89 & 0.0103 \\
\hline Year & 1 & 228684.96 & 26.28 & 0.0001 \\
\hline Block (year) & 4 & 10634.76 & 1.22 & 0.3747 \\
\hline Genotype $x$ year interaction & 14 & 12078.53 & 1.39 & 0.3501 \\
\hline Error & 56 & 8702.95 & & \\
\hline \multicolumn{5}{|l|}{$C V=30.55 \%$} \\
\hline \multicolumn{5}{|l|}{ Number of seed $/ \mathrm{m}^{2}$} \\
\hline Genotype & 14 & 100617.81 & 9.20 & 0.0001 \\
\hline Year & 1 & 860248.90 & 78.64 & 0.0001 \\
\hline Block (year) & 4 & 1322.80 & 0.12 & 0.7374 \\
\hline Genotype $x$ year interaction & 14 & 7474.83 & 0.68 & 0.3290 \\
\hline Error & 56 & 10938.88 & & \\
\hline \multicolumn{5}{|l|}{$C V=28.08 \%$} \\
\hline \multicolumn{5}{|l|}{ Mean seed weight } \\
\hline Genotype & 14 & 0.18 & 6.92 & 0.0001 \\
\hline Year & 1 & 0.02 & 0.75 & 0.0852 \\
\hline Block (year) & 4 & 0.01 & 0.27 & 0.7014 \\
\hline Genotype $x$ year interaction & 14 & 0.01 & 0.40 & 0.5740 \\
\hline Error & 56 & 0.03 & & \\
\hline $\mathrm{CV}=10.32 \%$ & & & & \\
\hline
\end{tabular}

between the number of seeds per $\mathrm{m}^{2}$ and the dry weight of the reproductive organs and the plant at date 5. From dates 3 to 5 , the number of seeds per $\mathrm{m}^{2}$ was positively correlated to the dry matter accumulated in the main stem. In contrast, dry weights of the tillers were negatively correlat- ed with the number of seeds per $\mathrm{m}^{2}$. A negative correlation was also noted between this characteristic and the dry weight of the plant at date 3 . The mean seed weight was positively correlated to the total dry matter accumulated by the plant and by the tillers at date 3 . These positive corre-

Table VII. Seed yield and yield components for the 1992 and 1993 seasons.

Yield component

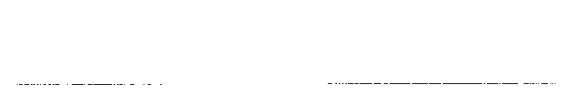

Yield $\left(\mathrm{t} \mathrm{ha} \mathrm{h}^{-1}\right)$

Number of pods $/ \mathrm{m}^{2}$

Number of seeds $/ \mathrm{m}^{2}$

Mean seed weight $(\mathrm{g})$ at $0 \%$ humidity
1992

$S E$

$\begin{array}{rr}\text { Mean } & S E \\ & \\ 3.84 & 0.72 \\ 373.20 & 1.90 \\ 039.10 & 0.91 \\ 0.37 & 0.02\end{array}$

1993

$\begin{array}{rr}\text { Mean } & S E \\ 2.96 & \\ 169.20 & 1.85 \\ 800.90 & 0.77 \\ 0.37 & 1.48 \\ & 0.01\end{array}$


Table VIII. Seed yield and yield components of 15 faba genotypes over two years.

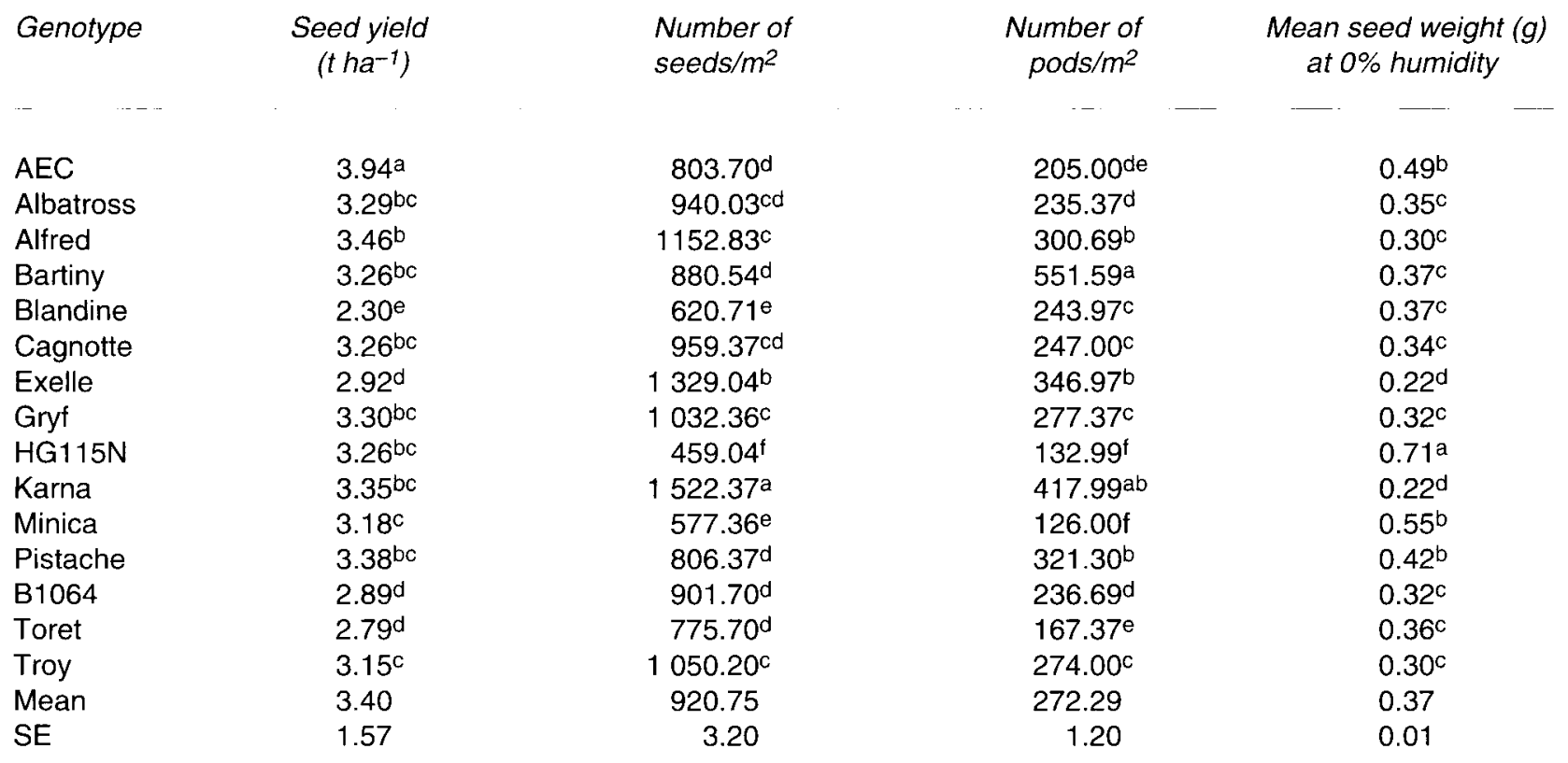

*Values followed by the same letter are not significantly different at the $5 \%$ probability level. SE: standard error.

lations might result from an indirect effect of the number of seeds per $\mathrm{m}^{2}$, because a significant correlation was found between mean seed weight and the number of seeds. In order to discard the effect of the number of seeds per $\mathrm{m}^{2}$, partial correlation coefficients were therefore cal- culated. No significant partial correlation was established between the dry weight of the tillers at date 3 and the mean seed weight, while for the dry weight of the plant at date 3 and the mean seed weight the partial correlation was only significant in $1992(r=0.628)$.

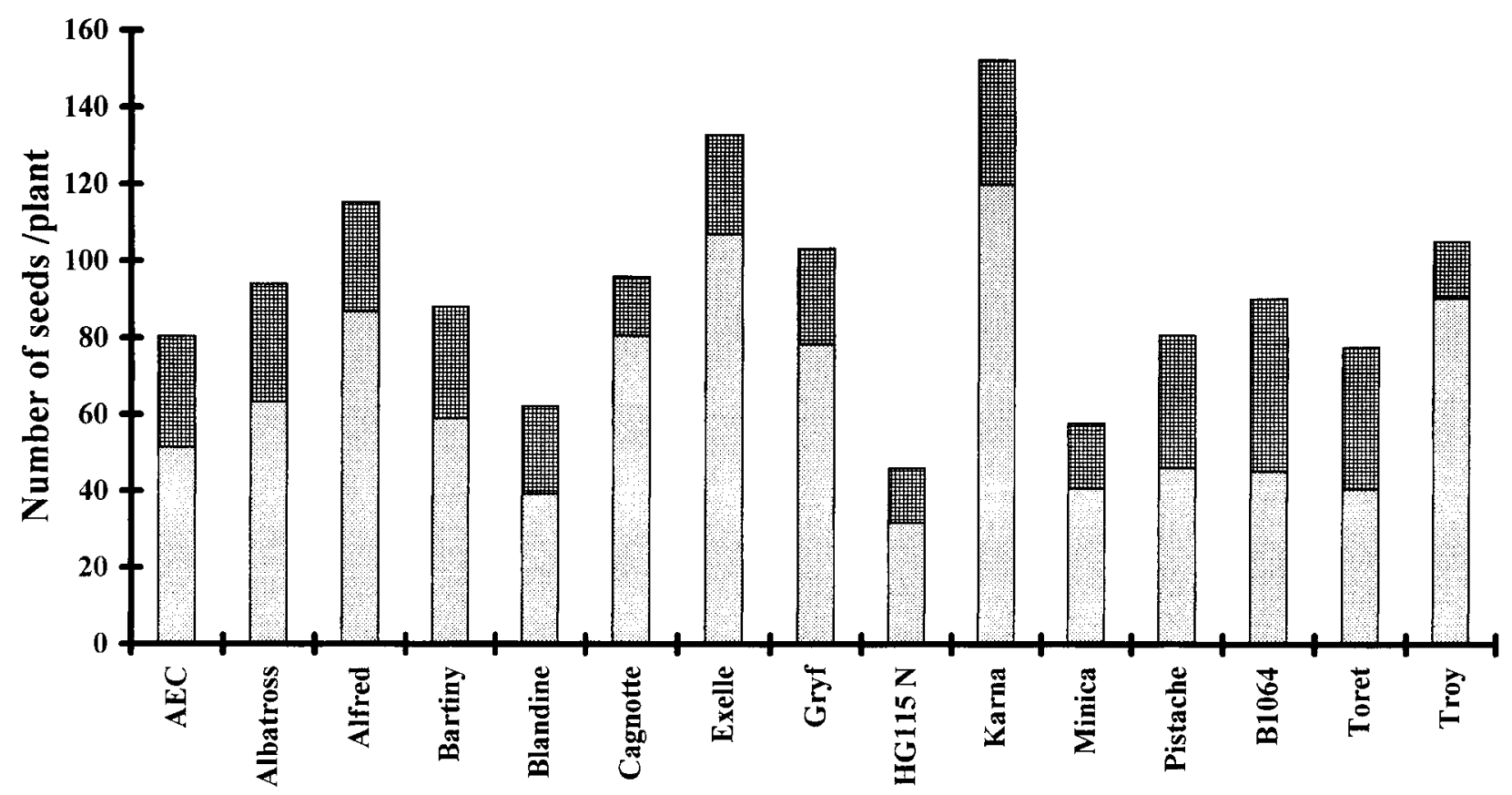

Fig 3. Distribution of seeds on the plant (main stem 
Table IX. Correlation coefficients for yield, yield components and total dry matter of plant and organs for 15 genotypes at sampling dates during the 1992 and 1993 seasons.

1992

SY

MSW

1.000

Seed yield (SY)

Mean seed weight (MSW)

Number of seeds $/ \mathrm{m}^{2}$ (NS/m²)

Reprodudtive dry matter at date 5

Vegetative dry matter at date 5

Main stem dry matter at date 5

Tillers dry matter at date 5

Plant dry matter at date 4

Main stem dry matter at date 4

Tillers dry matter at date 4

Plant dry matter at date 3

Main stem dray matter at date 3

Tillers dry matter at date 3

Plant dry matter at date 2

Tillers dry matter at date 2

$\begin{array}{ccc}0.560^{\mathrm{a}} & 1.000 & \\ 0.850^{\mathrm{b}} & -0.937^{\mathrm{b}} & 1.000 \\ 0.650^{\mathrm{b}} & - & 0.707^{\mathrm{b}} \\ - & - & 0.645^{\mathrm{b}} \\ - & - & 0.674^{\mathrm{b}} \\ - & - & - \\ 0.736^{\mathrm{b}} & - & - \\ - & - & 0.643^{\mathrm{b}} \\ - & - & - \\ - & 0.785^{\mathrm{b}} & -0.641^{\mathrm{b}} \\ - & -0.561^{\mathrm{a}} & 0.719^{\mathrm{b}} \\ - & 0.729^{\mathrm{b}} & -0.773^{\mathrm{b}} \\ - & - & - \\ - & - & -0.791^{\mathrm{b}}\end{array}$

1993

SY NSW NS/m $m^{2}$

$N S / m^{2}$

\subsection{0}

$0.548^{a}$

$0.750^{\mathrm{b}}$

$0.750^{b}$

$-$

$-$

$0.636^{a}$

$-$

$-$

$-$

$-$

$-$

$\begin{array}{cc}1.000 & \\ -0.755^{\mathrm{b}} & 1.000 \\ - & 0.757^{\mathrm{b}} \\ - & 0.695 \\ - & 0.543^{\mathrm{a}} \\ - & - \\ - & - \\ - & 0.648^{\mathrm{b}} \\ 0.584^{\mathrm{a}} & - \\ 0.560^{\mathrm{a}} & -0.602^{\mathrm{a}} \\ -0.564^{\mathrm{a}} & 0.590^{\mathrm{a}} \\ 0.546^{\mathrm{a}} & -0.564^{\mathrm{a}} \\ - & - \\ - & -0.643^{\mathrm{b}}\end{array}$

The threshold of significance at $5^{\mathrm{a}}$ and $1 \%^{\mathrm{b}}$ level, for $d f=13$; only significant correlation coefficients are indicated.

\section{DISCUSSION AND CONCLUSION}

For all characters analysed (dry matter, yield and yield components), the differences between the 1992 and 1993 seasons may have resulted from different climatic conditions, mainly rainfall, recorded during the growing period. From midflowering, the rainfall in 1993 was lower and more irregularly distributed than in the previous year. In 1993 the high water supply until the beginning of flowering allowed the crops to produce more biomass at dates 1 (during the vegetative phase) and 2 (beginning of flowering) than in 1992. However, from dates 3 to 5 , the low amount of dry matter accumulated in $1993 \mathrm{com}-$ pared to 1992 may have been due to the low rainfall and water deficit recorded from June onward. This result agrees with those obtained from experiments conducted under irrigation (Dantuma et al, 1983; Pilbeam et al, 1990; Grashoff, 1990). These studies also indicated that the reduction in dry matter production per $\mathrm{m}^{2}$ affects seed yield. This may explain the lower seed yield obtained in 1993 as a consequence of a lot of abortion of reproductive organs (Poulsen, 1974; Magyarosi and Sjödin, 1976). This is shown by the low number of pods per $\mathrm{m}^{2}$ in 1993. In contrast, environmental conditions seemed to have no influence on mean seed weight. Kriogman et al (1980), for different culti- vars of faba bean, also found that drought reduced the number of pods and seeds per $\mathrm{m}^{2}$, but had no effect on mean seed weight. However, the differences noted between mean seed weight of the 15 genotypes obtained in our experimental conditions and that reported by GEVES (1994) may be due to our experimental conditions (soil, weather, sowing date and sowing density) which did not allow attainment of potential mean seed weight.

The seed yield variation recorded between the two years resulted mainly from variation of the number of pods per $\mathrm{m}^{2}$, which decreased by $54 \%$ in 1993. However, the number of seeds per pod was higher in 1993 (on average five seeds) than in 1992 (on average three seeds). This result indicates that the main origin of seed yield variation resulted from variations in the number of pods per plant. Favourable growing conditions may permit an increase in the number of pods per plant but might favour abortions of seeds with pods under the effect of competition for assimilates between organs. It could also be the consequence of the production of pods at higher nodes, where the number of seeds per pod is likely to be lower.

For all the characters analysed, significant differences between faba been genotypes were found. Compared with indeterminate genotypes, the determinate B1064 genotype did not show 
any particular behaviour, except for the number of tillers per plant. Indeed, for B1064, the increase of dry matter per $\mathrm{m}^{2}$ from dates 3 to 4 coincided with the maximum number of tillers. This indicates that during pod-setting and seedfilling, B1064 sustained growth of new tillers development (ie, new competitor sinks). These tillers may generate high competition for assimilate distribution between organs, and then negatively affect seed yield. Pilbeam et al (1989b), Pilbeam et al (1990) and Stützel and Aufhammer (1992) have already established a strong relationship between tillering and competition for assimilates between vegetative and reproductive organs in $V$ faba, especially in determinate genotypes.

From dates 4 to 5 , the loss of total dry matter per plant recorded for all genotypes resulted mainly from senescent plant parts which fell before harvest. The large decrease in dry matter observed for Minica and B1064 (on average about $57 \%$ ) might be explained by the fact that B1064 and Minica showed more abortion of pods at stage II than other genotypes, as was observed during a previous experiment conducted under the same conditions (data not shown). We also noticed that Minica and B1064 lost more leaves and tillers than the other genotypes. B1064 had also barren branches at maturity. This can also explain the low seed yield of B1064 over both years of the experiment. Some authors (Baker et al, 1984; Silim and Saxena, 1992) reported that low seed yield of determinate faba bean genotypes may result from a tendency to grow more branches than can be brought to fructification, and these remain barren at maturity, thus wasting biomass in vain.

These results also showed a strong correlation between the dry matter accumulated per $\mathrm{m}^{2}$ at an early stage (date 1) and the size of the seeds sown. The relationship between these two characters may result partially from more dry matter in larger seeds than in smaller ones. This accumulation stimulates seed germination and seedling emergence. Studies with faba bean (Rowland and Gusta, 1977), pea (Hedley and Ambrose, 1981; Dumoulin, 1994) and white lupin (Huyghe, 1993) have shown that seedlings developed from large seeds were more vigorous than plants derived from small seeds.

At the flowering stage, early flowering genotypes accumulated more dry matter than late flowering ones. A strong correlation was established (although lower in 1993 than in 1992) between date of flowering of genotypes and total dry matter accumulated per $\mathrm{m}^{2}$ at this stage. This suggests that early genotypes present the highest growth rates, or that environmental conditions during dry matter accumulation were favourable during a longer period for early genotypes than for late ones.

Analysis of correlations let us identify more determining characters, which may influence dry matter in reproductive organs at maturity (date 5), seed yield and yield components. For both years, although the climatic conditions were different, relationships between these characters were similar. This shows that growth pattern was not modified by year. From dates 2 to 3 , the increase in the dry matter of the tillers was negatively related to the amount of total dry matter and to the reproductive dry matter accumulated at date 5. It was also negatively correlated to the number of seeds per $\mathrm{m}^{2}$. All genotypes, except hybrid $A E C$, followed this relationship. In fact, this result indicates that the presence of tillers is strongly associated with low total dry matter at date 5 and the number of seeds per $\mathrm{m}^{2}$. For these spring types of faba bean grown at a low plant density, it is likely that tillers induce a high competition for assimilates between organs, which may modify the partitioning of the biomass, with negative consequences on the dry matter in the pods at date 5 and on the number of seeds par $\mathrm{m}^{2}$. Concerning hybrid AEC, the presence of tillers was not associated either with its total dry matter accumulated at harvest or with its number of seeds per $\mathrm{m}^{2}$. The hybrid vigour of this genotype may permit a high early accumulation of dry matter in its tillers and a high accumulation of dry matter in its reproductive organs.

The partial correlation analysis indicates that the relationship between the mean seed weight and the dry weight of tillers at date 3 may result only from the indirect effect of the relationship noticed between the number of seeds and dry weight of tillers and from the relationship between the number of seeds per $\mathrm{m}^{2}$ and mean seed weight. In contrast, concerning the plant, partial correlations indicate that total dry matter accumulated by the plant at date 3 might directly affect mean seed weight, so that a high accumulation of dry matter by the plant at this date increases mean seed weight but reduces the number of seeds per $\mathrm{m}^{2}$. On the other hand, at date 3 , the positive correlation noted between the total dry matter accumulated in the main stem and the number of seeds per $\mathrm{m}^{2}$, and the negative relationship between the dry weight of the main stem and the mean seed weight, result only from the competition between the number 
of seeds per $\mathrm{m}^{2}$ and the mean seed weight. An opposition between an increase in the dry weight of the main stem and the tillers was also noticed. Within the limits of our experimental conditions, the increase in the dry weight of the tillers did not seem to contribute to increase either the number of seeds per $\mathrm{m}^{2}$ or the mean seed weight. This clearly shows the negative effect of an increase in tillering ability in spring genotype faba beans. Therefore, it might be more interesting in spring genotypes to develop a plant structure with a single stem.

We have also observed that the number of seeds per $\mathrm{m}^{2}$ is the yield component that shows the highest correlation with seed yield, and is therefore the most important component for yield improvement. This relationship has already been underlined by other authors on faba bean (Kambal, 1969), pea (Duthion et al, 1987b; Dumoulin, 1994) and soyabean (Lejeune-Henaut, 1992). In contrast, yield was less correlated with mean seed weight. Our results also identified a negative relationshp between the two main components of seed yield (number of seeds per $\mathrm{m}^{2}$ and mean seed weight). It seems that the genotype which formed a large amount of seeds per $\mathrm{m}^{2}$ showed the lowest seed weight. This may be due to an increased competition among sinks.

The hybrid AEC seems to better use its dry matter accumulated by tillers than other genotypes in the elaboration of its number of seeds. Le Guen and Duc (1992) have already underlined one superiority of faba bean hybrids for some characters. Analysis of correlations let us establish that the size of seeds sown and the date of flowering can be good indicators of vegetative vigour in faba beans. The dry weight of the main stem at date 3 seems to be a good and an early indicator of the number of seeds per $\mathrm{m}^{2}$ and the mean seed weight. A strong opposition between the dry weights of tillers and the main stem, allowing the identification of a competitive effect between these two types of organs, was also found.

\section{ACKNOWLEDGMENTS}

We are indebted to $C$ Huyghe, $L$ Saur and $M$ Trottet for their many helpful suggestions and valuable discussions and corrections throughout the preparation of this manuscript. We thank J Poisson, R Esnault, and G Morin for their technical assistance. This work was supported by the French Ministry of Cooperation and the Algerian Ministry of Agriculture. We also thank UNIP (Union nationale interprofessionelle des plantes riches en protéines) for its financial support of this project.

\section{REFERENCES}

Baker DA, Chapman GP, Standish MJ, Bailey MP (1984) Growth habit in relation to assimilate partitioning and some consequences for breeding. In: Vicia faba L: Agronomy Physiology and Breeding (PD Hebblethwaite, TCK Dawkins, MC Heath, G Lockwood, eds), Martinus Nijhoff/Dr W Junk, The Hague, 23-28

Berthelem P, Duc G, Le Guen J, Picard J (1984) Sélection de la féverole : situation actuelle et perspectives. Recueil des communications des journées nationales sur les protéagineux 53-56

Bond DA (1986) Yield stability of composite populations and inbred lines of winter beans (Vicia faba $\mathrm{L}$ ). Biol Zentralbl 105, 129-135

Bond DA (1987) Recent developments in breeding field beans (Vicia faba L). Plant Breed 99, 1-26

Chapman GP, Fagg CW, Peat WE (1979) Parthenocarpy and internal competition in Vicia faba L. Z Pflanzenphysiol 89, 119-127

Dantuma G, Thompson R (1983) Whole-crop physiology and yield components. In: The Faba Bean (PD Hebblethwaite, ed), Butterworths, 143-157

Dumoulin V (1994) Étude de la variabilité génétique chez le pois protéagineux (Pisum sativum $L$ ) pour l'élaboration du rendement. Importance des interactions génotype $x$ milieu. PhD Thesis, INA-PG, $232 p$

Duthion C, Amarger N, Mariotti A (1987a) Accumulation potentielle de matière sèche et d'azote chez le lupin blanc de printemps (Lupinus albus L). agronomie 8, 585-593

Duthion C, Ney B, Pigeaire A (1987b) Groupe Agrophysiologie du pois. Compte tenu des travaux effectués sur pois de printemps lors de la campagne 1986 (cv Finale, Amino, Solora). Doc Int $22 \mathrm{p}$

Egli DB, Guffy RD, Leggett JE (1985) Partitioning of assimilate between vegetative and reproductive growth in soybean. Agron J 77, 917-922

Filippetti A, De Pace $C$ (1983) Improvement of grain yield in Vicia faba $L$ by using experimental mutagenesis. I. Frequency and types of mutations induced by gamma-radiation. Genet Agrar XXXVII, 53-68

Gates P, Smith ER, Boulter D (1983) Reproductive physiology of Vicia faba L. In: The Faba Bean (PD Hebblethwaite, ed), Butterworths, 133-142

GEVES (1994) Plantes fourragères deuxième partie : protéagineux et fourragères annuelles. Bull Variétés, 19-44

Grashoff C (1990) Effect of pattern of water supply on Vicia faba L. 1. Dry matter partitioning and yield variability. Neth J Agric Sci 38, 21-44

Hedley CC, Ambrose MJ (1981) Designing 'leafless' plants for improving yields of dried pea. Adv Agron $31,805-810$

Huyghe $C$ (1993) Growth of white lupin seedlings during the rosette stage as affected by seed size. agronomie 13, 145-217 
Jaquiéry R, Keller ER (1978) La chute des fruits chez la féverole (Vicia faba $L$ ) en relation avec la disponibilité en assimilats marqués au ${ }^{14} \mathrm{C}$. Rev Suisse Agric 10, 4, 123-127

Julier B, Huyghe C, Papineau J (1993) Dry matter and nitrogen accumulation and seed yield in determinate autumn-sown white lupin (Lupinus albus $L$ ). agronomie 13, 877-889

Kambal A (1969) Components of yield and field beans, Vicia faba L. J Agric Sci Camb 72, 359-363

Koscielniak J, Wtadyslaw F, Augustyniak G (1990) Photosynthetic activity in different organs of field beans (Vicia faba $L$ minor) with indeterminate and determinate growth habit. Acta Physiol Plant 12, 95103

Krogman KK, McKenzie RG, Hobbs EH (1980) Response of faba bean yield, protein production, and water use to irrigation. Can J Plant Sci 60, 91 96

Le Guen J, Duc G (1992) La féverole. In: Amélioration des espèces végétales cultivées (A Gallais, $\mathrm{H}$ Bannerot, eds), 189-203

Lejeune-Henaut I (1992) Étude du comportement de deux variétés précoces de soja (Glycine max L cultivars Sito et Fiskeby) dans le nord de la France. PhD Thesis Université de Paris-Sud, $60 \mathrm{p}$

Magyarosi T, Sjödin J (1976) Investigations of yield and yield components in field bean (Vicia faba $L$ ) varieties with different ripening time. $Z$ Pflanzenzuecht 77, 133-144

Pilbeam CJ, Akatse JK, Hebblethwaite PD, Wright SD (1989a) Yield production in two contrasting forms of spring-sown faba bean in relation to water supply. Field Crops Res 29, 273-287
Pilbeam CJ, Hebblethwaite PD, Ricketts HE (1989b) The response of determinate and semi-determinate faba bean. J Sci Food Agric 53, 443-454

Poulsen MH (1974) Effect of mode of seed setting on yield and earliness in Vicia faba L. Z Pflanzenzuecht 72, 120-131

Poulsen MH (1977) Obligate autogamy in Vicia faba L. J Agric Sci Camb 88, 253-256

Rowland GG, Gusta LV (1977) Effect of soaking, seed moisture contant, temperature and seed leakage on germination of faba beans (Vicia faba) and peas (Pisum sativum). Can J Plant Sci 57, 401-406

Saxena MC, Silim SN, Murinda MV (1986) Build-up and partitioning of dry matter and yield of faba bean genotypes of differing plant type. In: Vicia faba. Cultivation, Breeding and Nitrogen Fixation (E Ebmeyer, G Robbelen, eds), Gottingen, Konrad Pachnicke, 55-66

Silim SN, Saxena MC (1992) Comparative performance of some faba bean (Vicia faba L) cultivars of contrasting plant types. I. Yield, yield components and nitrogen fixation. J Agric Sci Camb 118, 325-332

Sjödin J (1971) Induced morphological variation in Vicia faba L. Heriditas 67, 155-180

Stützel H, Aufhammer W (1992) Grain yield in determinate and indeterminate cultivars of Vicia faba $\mathrm{L}$, with different plant distribution patterns and population densities. J Agric Sci Camb 118, 343-352

Turc O (1988) Élaboration du nombre de graines chez le Pois (Pisum sativum L, cv Frisson, Finale et leurs homologues Afila) : influence du rayonnement intercepté et application au diagnostic cultural. PhD Thesis, Univ Sci Tech Languedoc, Montpellier, $95 p$ 